\title{
Flor Yeast Proteomics under a Biofilm and under a Non-Biofilm Forming Conditions: Biological Processes in which more abundant Proteins are involved
}

\author{
Jaime MORENO-GARCÍA ${ }^{11}$, Florin VARARU*2), Juan MORENO ${ }^{3)}$, M. Carmen MILLÁN ${ }^{11}$, \\ Juan Carlos MAURICIO ${ }^{1)}$, Teresa GARCÍA-MARTÍNEZ ${ }^{1)}$
}
${ }^{1)}$ Department of Microbiology, Severo Ochoa (C6) building, Agrifood Campus of International Excel- lence ceiA3, University of Cordoba, 14014, Cordoba, Spain.
${ }^{2)}$ University of Agricultural Sciences and Veterinary Medicine, 700490, Iasi, Romania.
${ }^{3)}$ Department of Agricultural Chemistry, Marie Curie (C3) building, Agrifood Campus of International
Excellence ceiA3, University of Cordoba, 14014, Cordoba, Spain.
${ }^{*}$ Coresponding author, e-mail: florinvararu@yahoo.com

Bulletin UASVM Horticulture 71(2) / 2014

Print ISSN 1843-5254, Electronic ISSN 1843-5394

DOI: $10.15835 /$ buasvmcn-hort:10321

\begin{abstract}
In the Sherry wine elaboration process carried out in specific regions around the world, Saccharomyces cerevisiae "flor" yeast develops a velum (biofilm) on the wine surface. This velum remains along several years during the so called "biological aging" process and it contributes to the typical wine organoleptic properties. Besides biofilm formation, some others biological processes are regarded as essentials for the flor yeasts to survive. The aim of this work is to identify other biological processes apart from the biofilm formation which can be required for the flor yeast to survive in a biological aging condition. OFFGEL fractionator coupled to LTQ Orbitrap XL MS equipment were used trying to identify the maximum possible number of proteins in a biofilm forming condition (BFC) and under a reference non-biofilm forming condition (NBFC). Further, proteins were quantified and sorted by biological processes GO Terms by using the SGD database. Higher abundant proteins related with nucleus organization, cellular respiration, oligosaccharide metabolic process were found in the BFC. In the NBFC, proteins related with RNA splicing, ribosomal subunit export from nucleus and protein dephosphorylation were more abundant. Biological processes mentioned in this study may be essential for the flor yeast to survive in a BFC such as wines biologically aged. Genetic experiments are needed to definitively confirm the necessity of these proteins synthesis. All together may lead to the genetic improvement of flor yeast strains aimed to enhance their survival during the biological aging process and hence the whole Sherry wine elaboration process.
\end{abstract}

Keywords: biological processes, flor yeast, proteome.

\section{INTRODUCTION}

Biological aging is a wine elaboration process carried in many different areas around the world. The production process of Fino wine from grapes grown in the Sherry or Montilla-Moriles region, is probably the best known type of wine obtained by biological aging. During its course, the color, texture, flavor and taste properties change due to the metabolism of a kind of yeast, commonly known as "flor yeasts", resulting in a special type of wine so called "Sherry wine" (Martínez et al., 1998; Mesa et al., 2000; Moyano et al., 2002; Muñoz et al., 2005; Peinado and Mauricio, 2009).

Flor yeasts have to face several harsh conditions for survival (low oxygen concentration, high ethanol concentration, low $\mathrm{pH}$, etc.) during biological aging where few organisms can survive. Consequently, more than $95 \%$ of the flor over the wines may be composed of Saccharomyces cerevisiae as this is the most adapted yeast to grow in this environment (Pozo-Bayón and MorenoArribas, 2011). Until now, some features have been suggested that make these yeasts survive 
(Alexandre, 2013). Biological processes like buoyancy and biofilm formation in the wine-air area allowing the yeast to reach an oxygen-rich zone where it is possible to catalyze ethanol or glycerol (Farris et al., 1993; Purevdorj-Gage et al., 2007); or an efficient antioxidant defense system that protect the yeast cells against reactive oxygen species (ROS) which come from the oxidative metabolism of non-fermentable carbon sources as ethanol or glycerol (Castrejon et al., 2002; Penate et al., 2001); are both examples of features that make flor yeast survival and proliferation possible under a condition such as biological aging.

Taking into account that proteins like other biological macromolecules such as polysaccharides and nucleic acids, are essential parts of organisms and participate in virtually every biological process within cells, a proteome analysis have been carried out in order to detect another biological processes important for the flor yeast to survive under the biological aging environment. Here, proteomics has been applied to the same flor yeast strain growth under two different conditions: a biofilm forming condition (BFC), as is the biological aging medium, and in a non-biofilm forming condition (NBFC) as a reference. A database search has been performed for the relation of proteins with the biological processes in which they are involved.

\section{MATERIALS AND METHODS}

Flor yeast Saccharomyces cerevisiae G1 strain (ATCC: MYA-2451), was used in this work. A population of $1 \times 10^{6}$ cells $/ \mathrm{mL}$ was inoculated in a biofilm formation medium or BFC $(0,67 \%$ $(\mathrm{w} / \mathrm{v})$ YNB without amino acids (Difco), 1\% w/v glycerol, $10 \mathrm{mM}$ of glutamic acid and $10 \%(\mathrm{v} / \mathrm{v})$ ethanol which was added after sterilization, without shaking during 29 days) and in the nonbiofilm formation medium or NBFC $(0,67 \%(\mathrm{w} / \mathrm{v})$ YNB without amino acids (Difco), 17\% glucose and $10 \mathrm{mM}$ of glutamic acid during shaking 12 hours). The process was carried out at $21^{\circ} \mathrm{C}$. All media were autoclaved at $120{ }^{\circ} \mathrm{C}$ for 20 minutes. Cells from the biofilm were harvested by suction and from the non-biofilm culture by centrifugation both in an initial phase when the cell viability was higher than $90 \%$. The resulting cellular pellet from each condition was resuspended in $1 \mathrm{~mL}$ extraction buffer supplemented with Protease Inhibitor Cocktail tablets, and cell wall was broken by vortexing in a Vibrogen Cell Mill. Glass beads as well as cell debris were discarded by centrifugation. Protein precipitation was carried out by overnight incubation at $-20{ }^{\circ} \mathrm{C}$ after addition of $10 \% \mathrm{w} / \mathrm{v}$ of trichloroacetic acid (TCA) and 4 volumes of icecold acetone to the supernatant. After incubation, samples were centrifuged and the protein pellet was vacuum dried and then resuspended in solubilization buffer. Protein concentration was estimated by Bradford assay (1976) and samples stored at $-80^{\circ} \mathrm{C}$ until proteins analysis.

The OFFGEL High Resolution kit pH 3-10 was used for protein preparative isoelectric focusing (IEF) in solution. Protein samples $(450 \pm 50 \mu \mathrm{g})$ were solubilized in Protein OFFGEL fractionation buffer, glycerol, and buffer with ampholytes and aliquots evenly distributed in a 12-well 3100 OFFGEL Fractionator tray. Preset program OG12PR00 separation limits were used following recommendations of the manufacturer: $4500 \mathrm{~V}$, $200 \mathrm{~mW}$, and $50 \mu \mathrm{A}$; starting voltage, 200-1500 V; ending voltage, $5000-8000 \mathrm{~V}$; after the application of $20 \mathrm{kVh}$, the protein separation zones were maintained at constant voltage. Peptides from each well were scanned and fragmented with the LTQ Orbitrap XL mass spectrometer equipped with a nano LC Ultimate 3000 system. The electrospray voltage was set to $1300 \mathrm{~V}$ and the capillary voltage to $50 \mathrm{~V}$ at $190 \mathrm{Co}$. The LTQ Orbitrap was operated in the parallel mode, allowing for the accurate measurement of the precursor survey scan $(400-1500 \mathrm{~m} / \mathrm{z})$ in the Orbitrap selection, a 60000 full-width at half-maximum (FWHM) resolution at $\mathrm{m} / \mathrm{z} 400$ concurrent with the acquisition of three CID Data-Dependent MS/MS scans in the LIT for peptide sequence, followed by three Data-Dependent HCD MS/MS scans $(100-2000 \mathrm{~m} / \mathrm{z})$ with $7500 \mathrm{FWHM}$ resolution at $\mathrm{m} / \mathrm{z} 400$ for peptide sequence and quantification. The normalized collision energies used were $40 \%$ for HCD and $35 \%$ for CID. The maximum injection times for MS and MS/MS were set to $50 \mathrm{~ms}$ and $500 \mathrm{~ms}$, respectively. The precursor isolation width was $3 \mathrm{Da}$ and the exclusion mass width was set to $5 \mathrm{ppm}$. Monoisotopic precursor selection was allowed and singly charged species were excluded. The minimum intensity threshold for MS/MS was 500 counts for the linear ion trap and 8000 counts for the Orbitrap. Database search was performed with Proteome Discoverer 1.0 (Thermo Fisher Scientific software, San José, CA. USA) against Uniprot including fixed modification 
Carbamidomethylation in Cys and proteome results were statistically analyzed with the Proteome Discoverer program.

To compare quantity of proteins detected in both conditions, a relative quantification has been carried by using the exponentially modified protein abundance index or emPAI (Ishihama et al., 2005): emPAI $=10^{\mathrm{PAI}}-1$. The PAI index is obtained by dividing the observed peptides (taking into account the charge state and missed cleavages) of a specific protein in the analysis by the observable peptides. The observable peptides were determined by using the "MS Digest" software". The protein relative contents in each condition were calculated using the next equation, being $\mathrm{Mr}$ the protein molecular weight: Protein content $($ weight $\%)=($ emPAI x Mr $/ \Sigma($ emPAI x Mr))x100.

Proteins detected have been submitted to biological process GO (Gene Ontology) terms aggrupation through SGD database. Biological processes with higher differences among conditions, depending on the number of specific proteins in the condition but also on the number of proteins more abundant in this condition, have been considered in depth. Moreover those biological processes with higher number of proteins in BFC than in NBFC have been highlighted.

\section{RESULTS AND DISCUSSION}

A total of 413 proteins were identified under BFC, 611 under NBFC and 207 under both (Fig. 1).

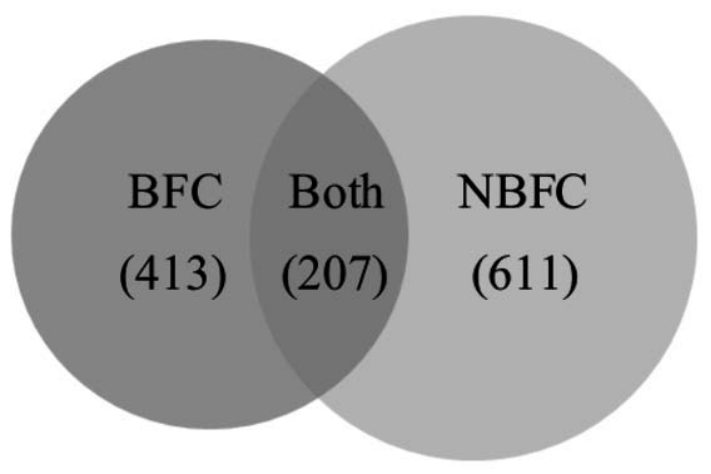

Fig. 1. Venn diagram showing proteins detected in the biofilm forming condition (BFC), in the non-biofilm forming condition (NBFC) and detected in both conditions.
These proteins were subjected to relative quantification through the EmPAI value and protein average content values of 0,24 in $\mathrm{BFC}$ and 0,16 in NBFC were calculated. There were reporting 65 more abundant under $\mathrm{BFC}, 45$ under NBFC and 97 with similar quantities under both conditions. After that, a GO Term searching for biological processes was performed for the specific proteins detected under BFC and under NBFC (206 and 404, respectively) and for the proteins with higher quantity under BFC and under NBFC (65 and 45, respectively). The following table shows the frecuency of proteins (comparing with the total number of proteins identified under each condition) annotated in a specific biological process. The highest differences among conditions were reported in the following biological processes: nuclear organization, cellular respiration and oligosaccharide metabolic process in the case of BFC (Fig. 2); and RNA splicing, ribosomal subunit export from nucleus and protein dephosphorylation in the case of NBFC.

Nucleus organization is a process that is carried out at the cellular level which results in the assembly, arrangement of constituent parts, or disassembly of the nucleus. This may explain the fact that in flor yeast has been regarded a genetic heterogeneity which at the same time has been associated with adaptation to a wine medium which is depleted in fermentable sugars and has high levels of ethanol and acetaldehyde (Martínez et al., 1998). This biological process could moreover be related to the flor yeast features as high heterozygosis degree (Budroni et al., 2000), aneuploidy (Guijo et al., 1997) and the high frequency of heterothallic life cycle up to $10 \%$ reported by Mortimer et al., 1994 . Kar2p was detected with a high content under the biofilm condition, this protein plays a role in the karyogamy or creation of a single nucleus from multiple nuclei, involved in conjugation with cellular fusion indicating that under this condition, sexual reproduction might be taking place. Furthermore, Kar3p participating as well in this process in an essential manner was detected only under BFC.

On the other hand, as it was expected, a high proportion of proteins were detected in $\mathrm{BFC}$ involved in the cellular respiration. This is explained since flor yeast metabolism is purely oxidative in biological aging conditions (Mauricio 


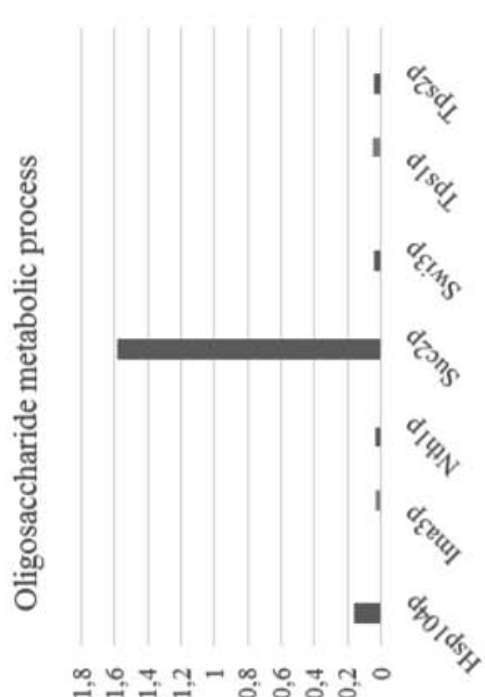

$\%$

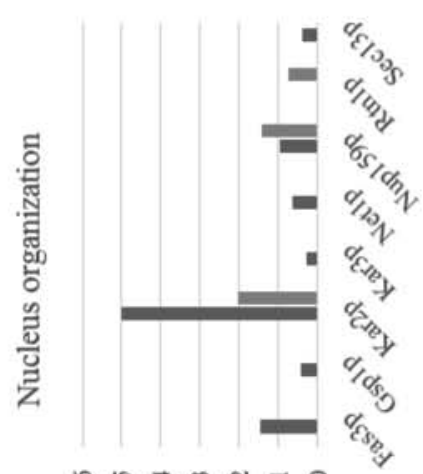

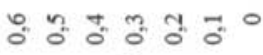

$\%$

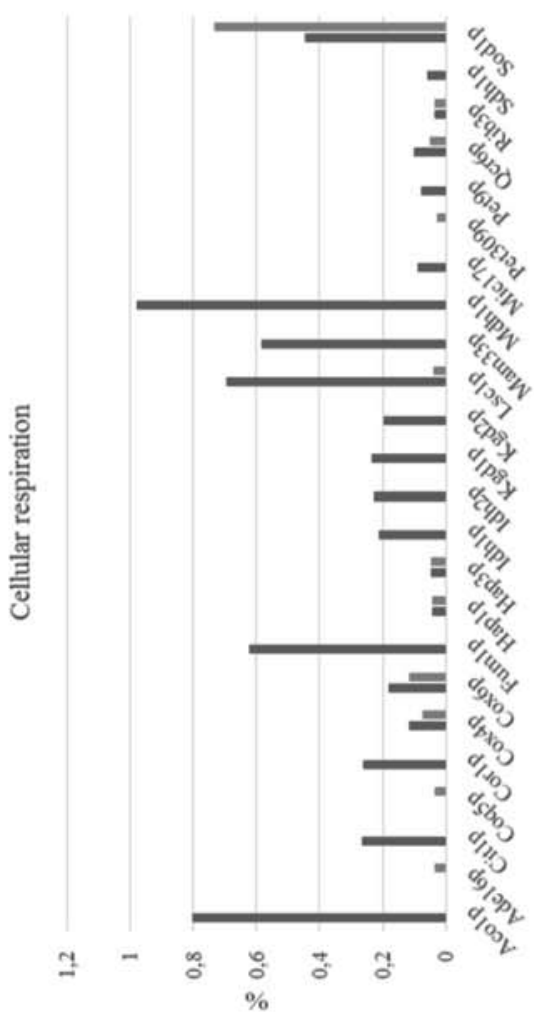

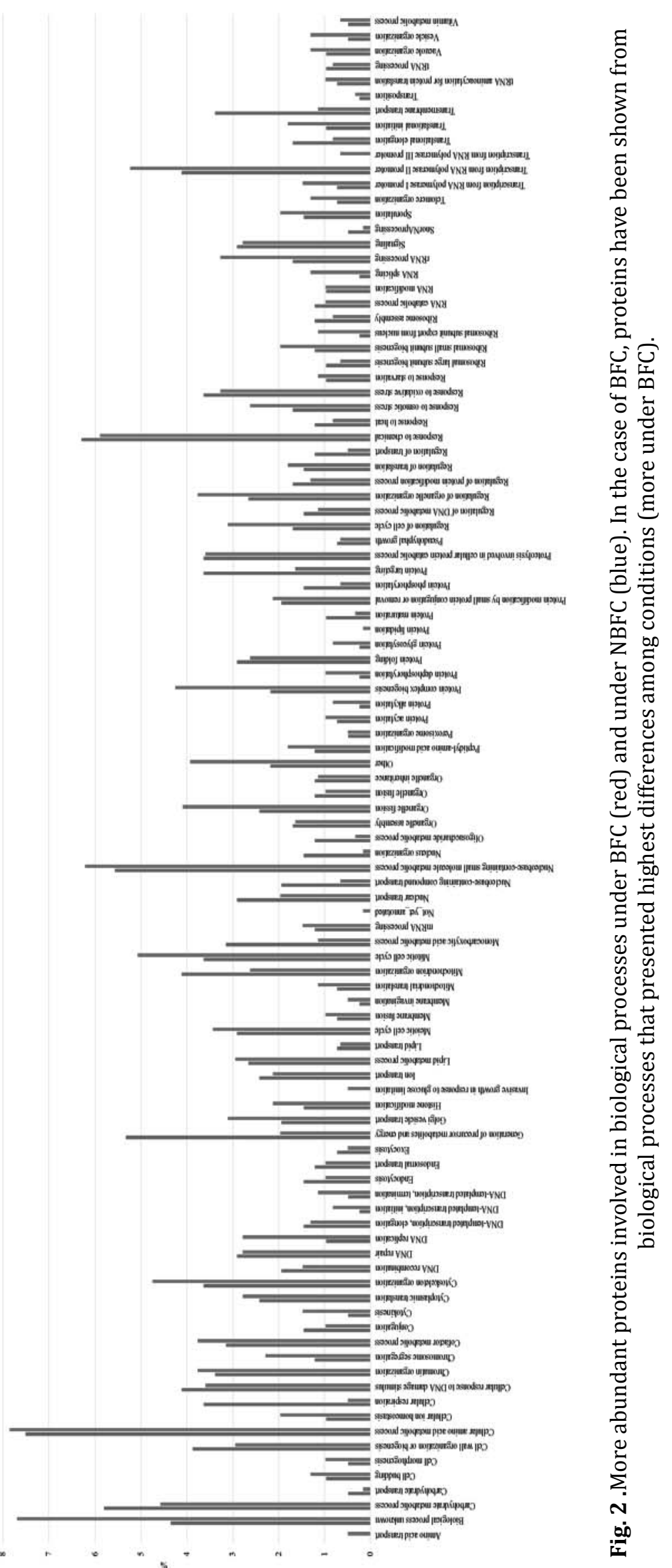


et al., 1997). In this type of environment lacking fermentable carbon sources, the only remaining carbon sources, ethanol and glycerol, can only be catabolized through an oxidative metabolism in which cellular respiration plays an important role. Aco1p detected with an abundance of up to 0,80 under BFC, apart of having a role in the cellular respiration, plays also an essential role in mtDNA maintenance which may be damaged by the reactive oxygen specied produced during cellular respiration (Moradas-Ferreira et al., 1996). Another protein detected with a high content under this condition was Mdh1p $(0,98$ in BFC and not under NBFC) that is a mitochondrial malate dehydrogenase that catalyzes interconversion of malate and oxaloacetate and involved in the tricarboxylic acid .

Not as expectedly, a high proportion of more abundant proteins were found to be involved in the oligosaccharide metabolic process. This could be regarded as a yeast starvation response to a medium in which there are not hexoses as carbon sources. Moreover a protein that is implicated in the consumption of sucrose was detected in a very high content. This was Suc2p.

Table 1 shows the proteins found in more abundance under the biofilm formation that are involved in the biological process mentioned. It is also indicated in which processes they participate specifically.

Much less abundant proteins were detected in BFC involved in RNA splicing, ribosomal subunit export from nucleus or protein dephosphorylation. The two first processes are important for organisms which are facing a new condition and need to build a new proteomic machinery as an adaptation response to the new environment. As in BFC, yeasts had more time to adapt to the

Tab. 1. More abundant proteins detected under BFC involved in the biological processes: nucleus organization, cellular respiration and oligosaccharide metabolic process. Isoelectric point (IP), molecular weight in Dalton (Mw) and Uniprot entry have been included.

\begin{tabular}{|c|c|c|c|c|c|c|}
\hline $\begin{array}{l}\text { Biological } \\
\text { process }\end{array}$ & \multicolumn{2}{|c|}{ Protein names } & I. P. & Mw & Entry & Gene ontology (biological process) \\
\hline \multirow{5}{*}{$\begin{array}{l}\text { Nucleus } \\
\text { organi- } \\
\text { zation }\end{array}$} & Acc1p & $\begin{array}{l}\text { Acetyl-CoA } \\
\text { carboxylase }\end{array}$ & 6.21 & 250318.7 & Q00955 & $\begin{array}{l}\text { Acetyl-CoA carboxylase activity; biotin carboxylase } \\
\text { activity; long-chain fatty acid biosynthetic process; } \\
\text { malonyl-CoA biosynthetic process; nuclear envelope } \\
\text { organization; protein import into nucleus }\end{array}$ \\
\hline & Gsp1p & $\begin{array}{l}\text { GTP-binding } \\
\text { nuclear } \\
\text { protein } \\
\text { GSP1/CNR1 }\end{array}$ & 6.52 & 24808.6 & P32835 & $\begin{array}{l}\text { Exonucleolytic trimming to generate mature 3'- } \\
\text { end of 5.8S rRNA from tricistronic rRNA transcript } \\
\text { (SSU-rRNA, 5.8S rRNA, LSU-rRNA); GTPase activity; } \\
\text { intracellular protein transport; nucleocytoplasmic } \\
\text { transport; nucleus organization; regulation of } \\
\text { chromatin silencing at telomere; small GTPase } \\
\text { mediated signal transduction }\end{array}$ \\
\hline & Kar2p & $\begin{array}{l}78 \mathrm{kDa} \\
\text { glucose- } \\
\text { regulated } \\
\text { protein } \\
\text { homolog }\end{array}$ & 4.53 & 74434.4 & P16474 & $\begin{array}{l}\text { ATPase activity; ATP catabolic process; ER- } \\
\text { associated ubiquitin-dependent protein catabolic } \\
\text { process; karyogamy involved in conjugation with } \\
\text { cellular fusion; posttranslational protein targeting } \\
\text { to membrane, translocation; response to unfolded } \\
\text { protein; SRP-dependent cotranslational protein } \\
\text { targeting to membrane, translocation }\end{array}$ \\
\hline & Kar3p & $\begin{array}{l}\text { Kinesin- } \\
\text { like protein } \\
\text { KAR3 } \\
\text { (Nuclear } \\
\text { fusion } \\
\text { protein) }\end{array}$ & 9.24 & 84013.6 & P17119 & $\begin{array}{l}\text { Karyogamy involved in conjugation with cellular } \\
\text { fusion; meiotic nuclear division; metabolic process; } \\
\text { minus-end-directed microtubule motor activity; } \\
\text { mitotic nuclear division; mitotic sister chromatid } \\
\text { cohesion; nuclear migration involved in conjugation } \\
\text { with cellular fusion }\end{array}$ \\
\hline & Net1p & $\begin{array}{l}\text { Nucleolar } \\
\text { protein } \\
\text { NET1 }\end{array}$ & 8.13 & 128533.6 & P47035 & $\begin{array}{l}\text { Chromatin silencing at rDNA; mitotic nuclear division; } \\
\text { nucleolus organization; regulation of exit from mitosis }\end{array}$ \\
\hline
\end{tabular}


Tab. 1 (continued)

\begin{tabular}{|c|c|c|c|c|c|c|}
\hline $\begin{array}{l}\text { Biological } \\
\text { process }\end{array}$ & & Protein names & I. P. & Mw & Entry & Gene ontology (biological process) \\
\hline $\begin{array}{l}\text { Nucleus } \\
\text { organi- } \\
\text { zation }\end{array}$ & Sec13p & $\begin{array}{l}\text { Protein transport } \\
\text { protein SEC13 }\end{array}$ & 5.54 & 33031.2 & Q04491 & $\begin{array}{l}\text { COPII-coated vesicle budding; ER-associated } \\
\text { ubiquitin-dependent protein catabolic process; } \\
\text { mRNA transport; nuclear pore distribution; } \\
\text { positive regulation of GTPase activity; positive } \\
\text { regulation of transcription, DNA-templated; } \\
\text { protein transport }\end{array}$ \\
\hline \multirow{12}{*}{$\begin{array}{l}\text { Cellular } \\
\text { respiration }\end{array}$} & Aco1p & $\begin{array}{l}\text { Aconitate hydratase, } \\
\text { mitochondrial }\end{array}$ & 8.15 & 85368 & P19414 & $\begin{array}{l}\text { Aconitate hydratase activity; mitochondrial } \\
\text { genome maintenance; tricarboxylic acid cycle }\end{array}$ \\
\hline & Cit1p & $\begin{array}{l}\text { Citrate synthase, } \\
\text { mitochondrial }\end{array}$ & 8.86 & 53360 & P00890 & $\begin{array}{l}\text { Acetyl-coa catabolic process; cellular } \\
\text { carbohydrate metabolic process; citrate (Si)- } \\
\text { synthase activity; citrate metabolic process; } \\
\text { glutamate biosynthetic process; tricarboxylic } \\
\text { acid cycle }\end{array}$ \\
\hline & Cor1p & $\begin{array}{l}\text { Cytochrome b-c1 } \\
\text { complex subunit } 1 \\
\text { mitochondrial }\end{array}$ & 7.34 & 50227 & P07256 & $\begin{array}{l}\text { Aerobic respiration; catalytic activity; hydrogen } \\
\text { ion transmembrane transport }\end{array}$ \\
\hline & Fum1p & $\begin{array}{l}\text { Fumarate hydratase, } \\
\text { mitochondrial }\end{array}$ & 8.26 & 53151 & P08417 & $\begin{array}{l}\text { Fumarate hydratase activity; fumarate } \\
\text { metabolic process; tricarboxylic acid cycle }\end{array}$ \\
\hline & Idh1p & $\begin{array}{l}\text { Isocitrate } \\
\text { dehydrogenase } \\
\text { [NAD] subunit } 1 \\
\text { mitochondrial } \\
\end{array}$ & 9.81 & 39324 & P28834 & $\begin{array}{l}\text { Glutamate biosynthetic process; isocitrate } \\
\text { dehydrogenase (NAD+) activity; isocitrate } \\
\text { metabolic process; tricarboxylic acid cycle }\end{array}$ \\
\hline & $\operatorname{Idh} 2 p$ & $\begin{array}{l}\text { Isocitrate } \\
\text { dehydrogenase } \\
\text { [NAD] subunit 2, } \\
\text { mitochondrial } \\
\end{array}$ & 9.15 & 39739 & P28241 & $\begin{array}{l}\text { Glutamate biosynthetic process; isocitrate } \\
\text { dehydrogenase (NAD+) activity; isocitrate } \\
\text { metabolic process; tricarboxylic acid cycle }\end{array}$ \\
\hline & $\operatorname{Kgd} 1 \mathrm{p}$ & $\begin{array}{l}\text { 2-oxoglutarate } \\
\text { dehydrogenase, } \\
\text { mitochondrial }\end{array}$ & 7.21 & 114415 & P20967 & $\begin{array}{l}\text { 2-oxoglutarate metabolic process; oxoglutarate } \\
\text { dehydrogenase (succinyl-transferring) activity; } \\
\text { tricarboxylic acid cycle }\end{array}$ \\
\hline & $\operatorname{Kgd} 2 p$ & $\begin{array}{l}\text { Dihydrolipoyllysine- } \\
\text { residue succinyl- } \\
\text { transferase } \\
\text { component of } \\
\text { 2-oxoglutarate } \\
\text { dehydrogenase } \\
\text { complex, } \\
\text { mitochondrial }\end{array}$ & 9.62 & 50430 & P19262 & $\begin{array}{l}\text { 2-oxoglutarate metabolic process; } \\
\text { dihydrolipoyllysine-residue succinyltransferase } \\
\text { activity; L-lysine catabolic process to acetyl- } \\
\text { coa via saccharopine; mitochondrial genome } \\
\text { maintenance; tricarboxylic acid cycle }\end{array}$ \\
\hline & Lsc1p & $\begin{array}{l}\text { Succinyl-CoA ligase } \\
\text { [ADP-forming] } \\
\text { subunit alpha, } \\
\text { mitochondrial } \\
\end{array}$ & 8.73 & 35032 & P53598 & $\begin{array}{l}\text { ATP citrate synthase activity; succinate-coa } \\
\text { ligase (ADP-forming) activity; succinyl-coa } \\
\text { metabolic process; tricarboxylic acid cycle }\end{array}$ \\
\hline & Mam33p & $\begin{array}{l}\text { Mitochondrial acidic } \\
\text { protein MAM33 }\end{array}$ & 4.34 & 30132 & P40513 & Aerobic respiration \\
\hline & Mdh1p & $\begin{array}{l}\text { Malate } \\
\text { dehydrogenase, } \\
\text { mitochondrial }\end{array}$ & 8.99 & 35650 & P17505 & $\begin{array}{l}\text { Aerobic respiration; cellular carbohydrate } \\
\text { metabolic process; chronological cell aging; } \\
\text { L-malate dehydrogenase activity; malate } \\
\text { metabolic process; replicative cell aging; } \\
\text { tricarboxylic acid cycle }\end{array}$ \\
\hline & Mic17p & $\begin{array}{l}\text { Mitochondrial } \\
\text { intermembrane } \\
\text { space cysteine motif- } \\
\text { containing protein } \\
\text { MIC17 }\end{array}$ & 8.53 & 16669 & Q03667 & Aerobic respiration \\
\hline
\end{tabular}


Tab. 1 (continued)

\begin{tabular}{|c|c|c|c|c|c|c|}
\hline $\begin{array}{l}\text { Biological } \\
\text { process }\end{array}$ & & rotein names & I. P. & Mw & Entry & Gene ontology (biological process) \\
\hline \multirow{3}{*}{$\begin{array}{l}\text { Cellular } \\
\text { respiration }\end{array}$} & Pet9p & $\begin{array}{l}\text { ADP,ATP carrier } \\
\text { protein } 2\end{array}$ & 10.61 & 34426 & P18239 & $\begin{array}{l}\text { ADP transport; aerobic respiration; } \\
\text { anaerobic respiration; apoptotic process; } \\
\text { ATP:ADP antiporter activity; ATP transport; } \\
\text { heme transport; mitochondrial transport; } \\
\text { transmembrane transport }\end{array}$ \\
\hline & Qcr6p & $\begin{array}{l}\text { Cytochrome b-c1 } \\
\text { complex subunit } 6\end{array}$ & 3.81 & 17257 & P00127 & $\begin{array}{l}\text { Aerobic respiration; hydrogen ion } \\
\text { transmembrane transport; mitochondrial } \\
\text { electron transport, ubiquinol to cytochrome c; } \\
\text { ubiquinol-cytochrome-c reductase activity }\end{array}$ \\
\hline & Sdh1p & $\begin{array}{l}\text { Succinate } \\
\text { dehydrogenase } \\
\text { [ubiquinone] } \\
\text { flavoprotein subunit, } \\
\text { mitochondrial }\end{array}$ & 7.47 & 70229 & Q00711 & $\begin{array}{l}\text { Cellular respiration; mitochondrial electron } \\
\text { transport, succinate to ubiquinone; succinate } \\
\text { dehydrogenase (ubiquinone) activity; } \\
\text { tricarboxylic acid cycle }\end{array}$ \\
\hline \multirow{5}{*}{$\begin{array}{l}\text { Oligosa- } \\
\text { ccharide } \\
\text { metabolic } \\
\text { process }\end{array}$} & Hsp104p & $\begin{array}{l}\text { Heat shock protein } \\
\qquad 104\end{array}$ & 5.2 & 102034 & P31539 & $\begin{array}{l}\text { Atpase activity, coupled; ATP catabolic process; } \\
\text { cellular heat acclimation; chaperone cofactor- } \\
\text { dependent protein refolding; inheritance } \\
\text { of oxidatively modified proteins involved } \\
\text { in replicative cell aging; protein folding in } \\
\text { endoplasmic reticulum; protein unfolding; } \\
\text { trehalose metabolism in response to heat stress }\end{array}$ \\
\hline & Nth1p & Neutral trehalase & 7.82 & 85879 & P32356 & $\begin{array}{l}\text { Alpha,alpha-trehalase activity; trehalose } \\
\text { catabolic process }\end{array}$ \\
\hline & Suc2p & Invertase 2 & 4.44 & 60639 & P00724 & $\begin{array}{l}\text { Beta-fructofuranosidase activity; fructan } \\
\text { catabolic process; inulinase activity; inulin } \\
\text { catabolic process; raffinose catabolic process; } \\
\text { sucrose alpha-glucosidase activity; sucrose } \\
\text { catabolic process }\end{array}$ \\
\hline & Swi3p & $\begin{array}{l}\text { SWI/SNF complex } \\
\text { subunit SWI3 }\end{array}$ & 4.6 & 92926 & P32591 & $\begin{array}{l}\text { ATP catabolic process; ATP-dependent } \\
\text { chromatin remodeling; carbon catabolite } \\
\text { activation of transcription from RNA } \\
\text { polymerase II promoter; cellular alcohol } \\
\text { catabolic process; positive regulation of } \\
\text { mating type switching; positive regulation } \\
\text { of transcription from RNA polymerase } \\
\text { II promoter; sucrose catabolic process; } \\
\text { transcription, DNA-templated }\end{array}$ \\
\hline & Tps2p & $\begin{array}{l}\text { Trehalose- } \\
\text { phosphatase }\end{array}$ & 8.19 & 102976 & P31688 & $\begin{array}{l}\text { Cellular response to heat; dephosphorylation; } \\
\text { trehalose biosynthetic process; trehalose- } \\
\text { phosphatase activity }\end{array}$ \\
\hline
\end{tabular}

new condition (29 days) these proteins were not as abundant as in the NBFC in which time from inoculation to sampling was 12 hours. With regard to protein dephosphorylation proteins in yeast they are mostly involved in the regulation of cell cycle, important in a yeast in an active reproducing stage which is not the case of BFC.

Nuclear organization proteins detected only or more abundant in BFC were specifically involved in processes like: karyogamy involved in conjugation with cellular fusion or nuclear migration involved in conjugation with cellular fusion; cellular respiration proteins in tricarboxylic acid cycle and oligosaccharide metabolic process proteins were involved in the sucrose catabolic process or trehalose biosynthetic process. 


\section{CONCLUSION}

Biological processes in which the more abundant proteins in a biofilm formation condition and in a non-biofilm formation condition were reported. These processes could play an important role in the studied conditions taking into account that proteins like other biological macromolecules participate in virtually every biological process within cells. As conclusion, it could be said that processes like nuclear organization, cellular respiration or oligosaccharide metabolic process may play an important role in the survival of the flor yeast during the biological aging condition and not as important, processes like RNA splicing, ribosomal subunit export from nucleus or protein dephosphorylation at the time of the sampling.

Acknowledgments. Spain's Ministry of Economy and Competitiveness and the European Community (FEDER), Grant RTA2011-00020-C02-02, MINECOINIA-CCAA.

\section{REFERENCES}

1. Alexandre H (2013). Flor yeasts of Saccharomyces cerevisiae-Their ecology, genetics and metabolism. Int. J. Food Microbiol, 167: 269-275.

2. Bradford MM (1976). A rapid and sensitive method for the quantitation of microgram quantities of protein utilizing the principle of protein-dye binding. Anal. Biochem. 72: 248-254.

3. Budroni M, Giordano G, Pinna G and Farris GA (2000). A genetic study of natural flor strains of Saccharomyces cerevisiae isolated during biological ageing from Sardinian wines. J. Appl. Microbiol. 89: 657-662.

4. Farris GA, Sinigaglia M, Budroni $M$ and Guerzoni $M$ (1993). Cellular fatty acid composition in film-forming strains of two physiological races of Saccharomyces cerevisiae. Lett. Appl. Microbiol. 17: 215-219.

5. Castrejon F, Codon AC, Cubero B and Benitez T (2002). Acetaldehyde and ethanol are responsible for mitochondrial DNA restriction fragment length polymorphism in flor yeasts. Syst. Appl. Microbiol. 25: 462-467.

6. Guijo S, Mauricio JC, Salmon JM and Ortega JM (1997). Determination of the relative ploidy in different Saccharomyces cerevisiae strains used for fermentation and « flor » film ageing of dry sherry-type wines. Yeast 13: 101-117.

7. Ishihama Y, Oda Y, Tabata T, Sato T, Nagasu T, Rappsilber $J$ and Mann M (2005). Exponentially modified protein abundance Index (emPAI) for estimation of absolute protein amount in proteomics by the number of sequenced peptides per protein. Mol. Cell. Proteomics, 4.9: 1265-1272.

8. Mantez P, Valcarcel MJ, Perez L and Benitez T (1998). Metabolism of Saccharomyces cerevisiae flor yeast during fermentation and biological aging of fino sherry: byproducts and aroma compounds. Am. J. Enol. Vitic. 49: 240-250.

9. Mauricio JC, Moreno J and Ortega JM (1997). In vitro specific activities of alcohol and aldehyde dehydrogenases from two flor yeasts during controlled wine aging. J. Agric. Food Chem. 45: 1967-1971.

10. Mesa JJ, Infante JJ, Rebordinos L, Sánchez JA and Cantoral JM (2000). Influence of the yeast genotypes on enological characteristics of sherry wines. Am. J. Enol. Vitic. 51: 15-21.

11. Moradas-Ferreira P, Costa V, Piper P and Mager W (1996). The molecular defences against reactive oxygen species in yeast. Mol. Microbiol. 19: 651-658.

12. Mortimer RK, Romano P, Suzzi G and Polsinelli M (1994). Genome renewal: a new phenomenon revealed from a genetic study of 43 strains of Saccharomyces cerevisiae derived from natural fermentation of grape must. Yeast 10: 1543-1552.

13. Moyano L, Zea L, Moreno J and Medina M (2002). Analytical study of aromatic series in sherry wines subjected to biological aging. J. Agric. Food Chem. 50: 7356-7361.

14. Muñoz D, Peinado RA, Medina M and Moreno J (2005). Biological aging of Sherry wines using pure cultures of two flor yeast strains under controlled microaeration. J. Agric. Food Chem. 53: 5258-5264.

15. Peinado RA and Mauricio JC (2009). Biologically aged wines, p. 81-103. In: Moreno-Arribas, M.V., Polo, M.C. (Eds.), Wine Chemistry and Biochemistry. Springer.

16. Penate X, Codon AC, Castrejon F and Benitez T (2001). Papel de la superóxido dismutasa en el velo de flor. II Congreso de la Sociedad Española de Genética, Sevilla.

17. Pozo-Bayón A, Moreno-Arribas V (2011). Sherry wines. Adv. Food Nutr. Res. 63: 17-40.

18. Purevdorj-Gage B, Orr ME, Stoodley P, Sheehan KB and Hyman LE (2007). The role of FLO11 in Saccharomyces cerevisiae biofilm development in a laboratory based flowcell system. FEMS Yeast Res. 7: 372-379. 